\title{
Constraints Faced and Suggestions Offered by Drip Adopted Farmers in Management of Drip Irrigation System
}

\author{
S. K. Raghuvansh ${ }^{1}$, J. K. Patel ${ }^{2}$ and C. D. Chauhan ${ }^{1}$ \\ ${ }^{1}$ Department of Extension Education, BACA, AAU, Anand- 388 110, India \\ ${ }^{2}$ Krishi Vigyan Kendra, AAU, Arnej -382 230, India \\ *Corresponding author
}

\section{A B S T R A C T}

\begin{tabular}{l} 
Ke y w or d s \\
Constraints, \\
Suggestions, \\
Management of \\
Drip Irrigation \\
System (DIS) \\
\hline Article Info \\
$\begin{array}{l}\text { Accepted: } \\
15 \text { November } 2019 \\
\text { Available Online: } \\
\text { 10 December } 2019\end{array}$ \\
\hline
\end{tabular}

The study was conducted under the domain of four districts viz., Chhotaudepur, Dahod, Botad and Kheda districts. A random sample of 200 drip adopted farmers was taken for study. The study reveals that required time-to-time attention for minor repairs $(92.50$ per cent) as most important constraint and occupied first position within the category. Followed by frequent clogging of drippers and micro tubes ( 89.50 per cent), lack of technical know-how (86.50 per cent), Problem of rate, pig, roz (84.00 per cent), Improper pressure hinders discharge rate (78.00 per cent), problems of water leakage in the DIS (75.00 per cent), proper water pressure maintain (71.00 per cent), Spare parts of drip irrigation system are costly (67.00 per cent). Majority of the drip adopted farmers endorsed suggestions for training should be imparted for betterment of knowledge/skill to use the system efficiently and effectively (95.50 per cent), provisions of regular guidance on maintenance and free service from company agents ( 93.00 per cent) and at least five years guarantee against DIS sets should be provided by company ( 85.50 per cent), The next notable suggestions given were, spare parts of the system should be available locally at reasonable rates (79.50 per cent). The other suggestions were and technical know-bow of the system should be provided through combination of media (73.00 per cent). Half of the drip adopted farmers (50.00 per cent) suggested for use of DIS in day-time.

\section{Introduction}

Drip irrigation is also known as trickle irrigation or micro irrigation is one of the latest innovations of irrigation technology which was developed in 1959 by water engineer, Simcha Blass, from Israel. In which micro irrigation water is applied at low pressure over a long period of time at frequent intervals directly into the plant's root zone through network of main lines, sub-mains and lateral lines with emission points spaced along their lengths. The emitter/dripper/orifice applies precisely of water, nutrient and other growth substances uniformly. Soil moisture is maintained slightly below field capacity. In this manner, with combined forces of gravity and capillarity, moisture and nutrients are 
replenished immediately and the plant does not suffer from water stress or water overdose. Micro irrigation ensures 30-70 per cent savings in water, 25-100 per cent increase in yields and 15-30 per cent reduction in operating crop production costs. It economizes energy usage around 50 per cent by reducing pumping hours and frictional losses. Resultantly, it can double the area under irrigation as well as improve quality of end product.

But still, there is a wide gap between adoption and management of the DIS, in this view a study was undertaken to find out the constraints faced by the drip adopted farmers in the management of DIS and their suggestions to overcome such constraints with the following objectives:

To identify the constraints faced by the drip adopted farmers in the management of DIS

To seek the suggestions from drip adopted farmers to overcome such constraints

\section{Materials and Methods}

The present investigation was carried out in Middle Gujarat which consists of nine districts (Ahmedabad, Anand, Chhotaudepur, Dahod, Kheda, Mahisagar, Panchmahal, Vadodara, and Botad). Among these, four districts viz., Chhotaudepur, Dahod, Botad and Kheda were selected purposively because these four districts having considerable higher number of drip adopted farmers. From each of selected district, one talukas were selected purposively having higher number of farmers who had adopted drip irrigation system. Among these four selected talukas, five villages from each of selected talukas were selected randomly. Thus, total twenty villages from four selected talukas were selected as area of study. From each selected village, ten farmers who had adopted drip irrigation system were selected by using random sampling method. Thus, total 200 drip adopted farmers were selected as sample in the study.

Considering the constraints faced by the drip adopted farmers in management of drip irrigation system and to overcome such constraints in management of drip irrigation system successfully, they were asked to give their valuable suggestions.

The suggestions offered were ranked on the basis of frequency and percentage of the drip adopted farmers who reported respective suggestions.

\section{Results and Discussion}

As far as the problems confronting the drip adopted farmers in management of drip irrigation system are concerned with their certain circumstances, it is well known fact that the constraints in management of improved technology can never be removed, but they may be minimized.

The drip adopted farmers were asked to express their constraints in management of drip irrigation system. Frequencies and per cent were computed and ranked accordingly. The data in this regard are presented in Table 1.

It is concluded from the Table 1 that, required time-to-time attention for minor repairs (92.50 per cent) as most important constraint and occupied first position within the category. Followed by frequent clogging of drippers and micro tubes (89.50 per cent), lack of technical know-how (86.50 per cent), Problem of rate, pig, roz (84.00 per cent), improper pressure hinders discharge rate $(78.00$ per cent), problems of water leakage in the DIS (75.00 per cent), proper water pressure maintain (71.00 per cent), Spare parts of drip irrigation system are costly (67.00 per cent). 
Inviting suggestions from the drip adopted farmers is always desirable as well as advantageous. They provide strong to make the programmed more perfect and viable by eliminating bottlenecks. Keeping this in view, the drip adopters were asked to suggest possible solutions to overcome the constraints associated with adoption of drip irrigation system. The suggestions were compiled and percentage was calculated to arrange them from highest to lowest percentage as presented in Table 2.

Table.1 Constraints faced by drip adopted farmers in management of drip irrigation system

\begin{tabular}{|c|c|c|c|c|}
\hline $\begin{array}{c}\text { Sr. } \\
\text { No. }\end{array}$ & Constraints & Number & $\begin{array}{c}\text { Per } \\
\text { cent }\end{array}$ & Rank \\
\hline $\mathbf{1 .}$ & Required time-to-time attention for minor & 185 & 92.50 & I \\
\hline repairs & Frequent clogging of drippers and micro tubes & 179 & 89.50 & II \\
\hline $\mathbf{3 .}$ & Lack of technical know-how & 173 & 86.50 & III \\
\hline $\mathbf{4 .}$ & Problem of rate, pig ,roz & 168 & 84.00 & IV \\
\hline $\mathbf{5 .}$ & Improper pressure hinders discharge rate & 156 & 78.00 & V \\
\hline $\mathbf{6 .}$ & Problems of water leakages in the system & 150 & 75.00 & VI \\
\hline $\mathbf{7}$ & Difficult to keep proper water pressure & 142 & 71.00 & VII \\
\hline $\mathbf{8}$ & Spare parts of drip irrigation system are costly & 134 & 67.00 & VIII \\
\hline
\end{tabular}

Table.2 Suggestions to overcome the constraints faced by the drip adopted farmers regarding management of drip irrigation system

\begin{tabular}{|c|c|c|c|c|}
\hline $\begin{array}{c}\text { Sr. } \\
\text { No. }\end{array}$ & Number & $\begin{array}{c}\text { Per } \\
\text { cent }\end{array}$ & Rank \\
\hline $\mathbf{1 .}$ & $\begin{array}{c}\text { Training should be imparted for betterment of } \\
\text { knowledge/skill to use the system efficiently } \\
\text { and effectively }\end{array}$ & 191 & 95.50 & I \\
\hline $\mathbf{2 .}$ & $\begin{array}{c}\text { Provisions of regular guidance on } \\
\text { maintenance and free service from company } \\
\text { agents }\end{array}$ & 186 & 93.00 & II \\
\hline 3. & $\begin{array}{c}\text { At least five years guarantee against DIS sets } \\
\text { should be provided by company }\end{array}$ & 171 & 85.50 & III \\
\hline 4. & $\begin{array}{c}\text { Spare parts of the system should be available } \\
\text { locally at reasonable rates }\end{array}$ & 159 & 79.50 & IV \\
\hline 5. & $\begin{array}{c}\text { Technical know-how of the system should be } \\
\text { provided through combination of media }\end{array}$ & 146 & 73.00 & V \\
\hline 6. & Use of DIS in day-time & 100 & 50.00 & VI \\
\hline
\end{tabular}

A perusal of data presented in Table 2 revealed that a thumping majority of the drip adopters endorsed suggestions for training should be imparted for betterment of knowledge/skill to use the system efficiently and effectively ( 95.50 per cent), provisions of regular guidance on maintenance and free service from company agents ( 93.00 per cent) and at least five years guarantee against DIS sets should be provided by company ( 85.50 
per cent), The next notable suggestions given were, spare parts of the system should be available locally at reasonable rates $(79.50$ per cent). The other suggestions were and technical know-bow of the system should be provided through combination of media (73.00 per cent). Half of the drip adopters (50.00 per cent) suggested for use of DIS in day-time

From the whole discussion, it could be concluded that the important suggestion endorsed by the drip adopted farmers to overcome the constraint faced by them in management of drip irrigation system were, training should be imparted for betterment of knowledge/skill to use the system efficiently and effectively, provisions of regular guidance on maintenance and free service from company agents, at least five years guarantee against DIS sets should be provided by company, spare parts of the system should be available locally at reasonable rates, technical know-bow of the system should be provided through combination of media, use of DIS in day-time.

\section{References}

Patel K. M. (2007). Time-Lag in Adoption of Tissue Culture Raised Banana Plants for Middle Gujarat. Ph.D. (Agri.) Thesis (unpublished), Anand Agricultural University, Anand.

Parmar S.D. and Thorat G.N. (2016). Constraints faced by farmers in drip irrigation system. Agric. Update, 11(3): 229-233.

Parmar S. D. (2008). Discriminate Functional Analysis of Adoption Dynamics In Relation to Drip Irrigation System In Middle Gujarat. Ph.D. (Agri.) Thesis (unpublished), Anand Agricultural University, Anand.

\section{How to cite this article:}

Raghuvansh, S. K., J. K. Patel and Chauhan, C. D. 2019. Constraints Faced and Suggestions Offered by Drip Adopted Farmers in Management of Drip Irrigation System. Int.J.Curr.Microbiol.App.Sci. 8(12): 1776-1779. doi: https://doi.org/10.20546/ijcmas.2019.812.212 